\title{
Women and Globalisation in India
}

\author{
Dr. K.G. Mallikarjuna, \\ Asst. Professor of Economics, SBSYM Degree College, Kurnool.
}

Keywords: Economic improvement, political empowerment, women education, women health and modern day slavery.

\section{Introduction}

Globalization has brought both fears and hopes to the people of the world. It has had different effects on the various communities of developed and developing countries, cities, suburbs, men and women.

The impacts of globalization on women are more prevalent and more complicated. Highlighting the positive aspects of globalization, a number of economists believe that women have mainly acquired noticeable benefits from economic reforms. One of the opportunities that globalization has provided for women is the increase in employment. By expanding mass communication Medias, globalization has also boosted women's awareness level so that they have better chance to prove themselves and have more chances for selection as well.

This Issue in Depth will examine the effects of globalization on women worldwide, namely on their participation in the economy, representation in the political process, education, health, and sexual slavery. It also will discuss the possibility of globalization's ability to greatly benefit women in the internationalization of the movement for gender equality, and the legal structure that supports this goal and recognizes women's rights as basic human rights.

\section{Participation in the economy}

The International Monetary Fund and the World Bank encourage developing countries to use exportled growth to expand their economies. Such globalized economies require a labor force of a size that must include women, but women's employment varies greatly by region. For example, as of 2010, 67 percent of women are in the work force in East Asia, the greatest proportion among all regions of the world. The global average is 53 percent (Viswanathan, 2010).Women in this part of the world participate for the longest part of their lives in comparison to other regions.

In the Middle East, these numbers are much lower, as of 2010, 36 percent in Qatar, 15 percent in Saudi Arabia, and 14 percent in the United Arab Emirates (Attwod, 2010, and Women's share, 2010).

The vastly different percentages around the world may be attributed to socialcultural factors, such as the belief in many ethnically Arab nations that women do not work, or the tight political control over women in places such as Saudi Arabia.

Similarly, South American women participate in the labor force more as they age, which indicates that they must contribute more income as their household grows following marriage, while women in the Middle East and North Africa drop out of the labor force in great numbers when they marry and have children.

\section{Indian context}

For women, the impact of globalisation has been uneven. A small layer have gained work opportunity in terms of newly emerging forms of employment, especially in the IT, service and food-processing sectors, but the semi-/unskilled ones have lost control over their natural recourses (land, water forest etc), as well as in traditional industries, resulting in the loss of traditional livelihood and sustainability. Gender is not a homogeneous category, but is intersected by class, caste, community and ethnicity, and impacted by age, ideology and sexual preference.

Even among leftists, there exist various views on globalisation. Rohini Hensman argues that an 'antiglobalisation' agenda would actually deprive third-world women of job opportunities and improving their conditions. She argues that talk of alternatives at the present juncture is to dream, and reality demands recognizing that some job is better than no job. Even if trade unions have collapsed due to capitalist offensives, jobs for some women enable them to survive, be independent of male relatives and feed their families. 


\section{Schemes for Economic Empowerment of women in the context of Globalisation 4.1.1 Support to Training \& Employment Programme for Women (STEP)}

A Central Sector Scheme launched in 1986-87, seeks to upgrade skill of poor and assetless women and provide employment on sustainable basis by mobilizing them in viable cooperative groups, strengthening marketing linkages, support services and access to credit. The scheme also provides for enabling support services in the form of health check-ups, legal and health literacy, elementary education, gender sensitization and mobile crèches.

\subsubsection{Rajiv Gandhi Scheme for Empowerment of Adolescent Girls (RGSEAG)}

'Sabla', a Centrally-sponsored scheme was approved by the Government on 16.8.2010. The scheme is being implemented in 200 districts across the country on a pilot basis. In the remaining districts, Kishori Shakti Yojana (KSY) continues to be operational as before. However, SABLA has completely replaced Nutrition Programme for Adolescent Girls (NPAG) as all districts of NPAG are now part of the SABLA. The scheme, interalia, aims at vocational training for girls above 16 years of age for their economic empowerment.

\subsubsection{Central Social Welfare Board (CSWB)}

In order to address the socio-economic needs of the women and children of selected eight most backward districts in the North Eastern region in the economic arena, Central Social Welfare Board has formulated the Integrated Scheme for Women Empowerment (ISWE). The scheme is being implemented on pilot basis since 2008 and has the objective of meeting the felt needs of the area by mobilizing community action, converging available services and resources of the area, income generation through feasible and sustainable activities for women and to provide services for health awareness, career counseling vocational training, preventing child trafficking and other social evils.

\subsection{Economic Improvement}

\subsubsection{National Mission for Empowerment of Women}

The extent of empowerment of women from a holistic and macro-point of view is largely determined by 3 factors viz. economic, social and political identity. These factors are deeply intertwined and linked with many cross cutting linkages. It implies that if efforts in any one dimension remains absent or week, the outcome and momentum generated by the other components cannot be sustained. It is only when all these three factors are addressed simultaneously and made compatible with each other can women be truly empowered. Therefore, for the holistic empowerment of women, an inter-sectoral approach has to be adopted.

\subsubsection{Rashtriya Mahila Kosh - (National Credit Fund for Women)}

The Rashtriya Mahila Kosh (National Credit Fund for Women) was set up in 1993 with a corpus of Rs. 31 crore, against the backdrop of socio-economic constraints faced by poor women to access micro - credit from the formal financial system in the country, especially those in the rural and in unorganized sectors. The principal corpus has increased to Rs. 100.00 crore by 2009-10. The main objective of setting up of Rashtriya Mahila Kosh (RMK) under the Department of Women and Child Development (now Ministry) was to provide micro-credit to poor women for various livelihood support and income generating activities at concessional terms in a client-friendly procedure to bring about their socio-economic development.

\subsubsection{Gender Budgeting and Economic Empowerment of Women}

Budgets, which influence the overall level of national income and employment and reflect the priorities of the government regarding public investment, also promote gender equality within the national development framework. The Government of India is committed to promoting gender equality and has adopted Gender Budgeting (GB) as a tool to address the inequalities faced by women. The purpose is to ensure the translation of Government's policy commitments on gender equity into budgetary allocations.

\section{Globalisation - Political Empowerment Of Women}

Women's participation in mainstream political activity has important implications for the broader arena of governance in any country. Governance relates to a set of rules, institutions, and values that are involved in the management of state and society.

The under representation of women in the political sphere is inextricably linked with the low and inferior status of women in society in India especially in the context of the declining sex ratio increasing violence and crimes against women and their marginalized status in employment, education and health sectors.(Human Development in South Asia:2000). The comparative position of gender-related development index (GDI) reveals that among 177 countries, India ranks 113th, indicating its very low gender-equity status. 
Although the gap between male and female literacy rates has been narrowing, there is still very large disparity in this regard. While male literacy rate in India is 75.3 per cent, female literacy rate is only 53.7 per cent. It is even worse among Scheduled Castes (SC) and Scheduled Tribes (ST). Among, the SC 50 per cent males are literate, while only 24 per cent females can read and write and among ST, 41 per cent males and only 18 per cent females are literate.

\subsection{The case for women's wider participation and representation}

Women in India constitute nearly half the population of the country, but they are poorly represented in the various governance and decision making bodies. The position depicted through the 14 general elections so far reflects a low representation of women in Parliament, State legislatures, in political parties and other decision-making bodies. Less than $8 \%$ of Parliamentary seats, less than $6 \%$ Cabinet positions, less than $4 \%$ of seats in High Courts and the

Supreme Court, have been occupied by women. Less than $3 \%$ of the administrators and managers are women. The average percentage of women's representation in the Parliament, Assemblies and Council of Ministers taken together has been around 10\%. (UNIFEM:2000).

\subsection{Political Mobilization and Participation}

Historically many women have been active in the informal political sphere in terms of political mobilization and they have participated in large numbers in political demonstrations and mass agitations as well as in the activities of nationalist and political bodies and organizations. The political mobilization and participation of women has been impressive in the Indian National Movement, in revolutionary Left movements, anti-price rise stirs, on legislation on rape, against the practice of widow immolation, in the antiliquor movements and movements against deforestation etc.

It is worth noting that the political mobilization of women and their participation in elections has steadily increased since the first General Elections of 1952. . Between 1952 -1980 for instance, women's participation increased by $12 \%$ against the turnout of men which increased by only $6 \%$. In the general elections of 2004, the all India percentage of women voter turnout was $48 \%$. As regards women voters' turnout, from 37.1 per cent in the first general elections in 1952 it increased gradually over the years to 55.6 by 1999 . Notably, the gap between female and male voters was 15.9 per cent in 1952, but it decreased slowly over successive elections and came down to 8.4 per cent in 1996. It has remained at 8.3 per cent in 2004 general elections. This percentage increase in the turnout of women in elections has however not translated into a larger number of women being represented in the legislative bodies.

Though voting is an important indicator of political participation and mobilization, it is not necessarily indicative of representation. Voting is a tool of political equality and it mobilizes women but voting by itself does not result in the desired end of equality.

\subsection{Representation}

Mainstream political parties became conscious of women as a constituency and this was reflected in their election manifestoes and their considering women as candidates with potential votes. By the ninth Lok Sabha elections in 1989, one could find a conscious focus on women's issues in the manifestoes of political parties. More recently major political parties have indeed made a conscious effort to induct more women into the various levels of the party organization. The CPM has made an effort to induct more women into its district committees and state level bodies. The BJP had the highest percentage of women in decision-making bodies from the Parliamentary Board and the Election Committee down to the ward level. (Rita Manchanda:1998). Traditionally, the Congress Party has fielded the largest number of women candidates and has had the largest number of women members in Parliament though the Congress working Committee has a rather low level of representation of women.

\subsection{Power rather than Representation}

The real reason for the low political representation of women in the formal political structures and decision making levels, seems to lie in the compulsions of competitive elections and the quest for power by the political parties in a multiparty democracy. Increasingly the compulsions of the political parties due to narrow majorities, precarious coalitions and hung parliaments have made the question of power rather than that of representation the determining factor.

Women's issues and women's participation and representation are encouraged only within the parameters of power and are constrained by the basic objectives and interest of the parties either to capture power or survival, if in power. 


\subsection{Women of Power and Women in power in Indian Politics}

In spite of the low political representation of women in Indian politics, it must be noted that some women leaders have an important place in Indian politics today. Jayalalithaa as leader of AIADMK, Mamata Bannerji as leader of Trinamul Congress and Mayawati as leader of Bahujan Samaj Party (BSP) are instances in point. Some of them head important and strong regional political parties which have been in alliance with major national political parties both outside and in national government.

\subsection{Representation through Reservation}

Various strategies have been proposed to further the political representation of women in India. From a reservation of $33 \%$ seats at various levels including the Parliament, it has also been suggested that political parties reserve $33 \%$ of their seats for women in the elections. The Bharatiya Janata Party recently announced such a reservation in its organization.

\section{Globalisation And Women Education}

Education to an individual means development of various kinds. It leads to social development, economic development, cultural development and many things else. Education gives vision and Vision gives mission. Vision is very much important for the transformation of the Society. The empowerment aspect of the development has an importance. Globalization no doubt has broadened the scope of education, particularly for countries with good levels of education. Similarly it helped in building human capital rests in both the content and methodology of education, which in turn shapes students to cope with the challenges thrown by globalization. In a developing nation like India, globalization is a sudden thrust.

Education and globalization seem to be more intricately related to each other. On the one hand, globalization impacts education, on the other education facilitates globalization. Such relationships vary among countries depending upon their level of development. Whereas developed countries derive significant benefit out of globalization, developing countries perceive it as a significant thrust for out-flow of resources and increasing gap between the developed and developing countries. Globalization is raising the stake in terms of opportunities for poverty reduction and the potential cost of policy mistakes.

In the context of globalization women education is given very importance. The changes in women education at various levels due to globalization is discussed below.

\subsection{Enrollments}

The growth of sex-wise school enrolment in different stages of school education from 1990-91 to 20042005 is observed. The total enrolment at the Primary stage has increased 97.4 million in 1990-91 to 130.8 million in 2004-05. In case of Upper Primary stage, it increased 34.0 million in 1990-91 to 51.2 million in 200405. The increase in enrolment at Secondary/Senior Secondary 19.1 million in 1990-91 to 37.1 million in 200405. The girls' enrolment increased at primary level 40.0 million in 1990-91 to 61.1 million in 2004-05. In case of Upper Primary stage, it increased 12.5 million in 1990-91 to 22.7 million in 2004-05. The increase in enrolment at Secondary/Senior Secondary 6.3 million in 1990-91 to 15.4 million in 2004-05. At primary education the boys are enrolled 57.0 million, girls were 40.0 million in 1990-91 in 2004-05 boys were 69.7 million and girls were 61.1 million enrolled. In case of Upper Primary stage the boys were 21.5 million and girls were 12.5 million enrolled in 1990-91 academic year. In 2004-05 boys were 28.5 million, girls were 22.7 million enrolled. At Secondary/Senior Secondary boys were 12.8 million, girls were 6.3 million enrolled in 1990-91 academic year. And in 2004-05 boys were 21.7 million, girls were 15.4 million.

\subsection{Enrollments of Schedule Caste girls in educational institutions}

In 1990-91 the total enrolment in primary level was 15794 which covered boy were 9737 i.e. $61.64 \%$ and girls were 6057 i.e. $38.36 \%$. In 2004-05 the total enrolment was 24737 which covered boys were 13762 i.e. $56.64 \%$ and girls were 10995 i.e. $44.46 \%$. In Upper primary level the total enrolment was 4160 which cover boys were 2747 i.e. $66.03 \%$ and girls were 1413 i.e. $33.97 \%$ in $1990-91$. And in $2004-05$ the total enrolment was 8697 which covered boys were 5100 i.e. $58.64 \%$, girls were 3597 i.e. $41.36 \%$. Sec./Sr. Sec level in 1990-91 the total enrolment was 2338 which covered boys were 1703 i.e. $72.85 \%$, girls were 635 i.e. $27.15 \%$. In the year 2004-05 enrolment was 5218 which covered boys were 3228 i.e. $61.86 \%$, girls were 1990 i.e. $38.14 \%$ respectively.

\subsection{Enrollments of Schedule Tribe girls in educational institutions}

In 1990-91 the total enrolment in primary level was 7869 which covered boy were 4958 i.e. $63.00 \%$ and girls were 2911 i.e. $37.00 \%$. In 2004-05 the total enrolment was 13737 which covered boys were 7367 i.e. $53.62 \%$ and girls were 6369 i.e. $46.38 \%$. In Upper primary level the total enrolment was 1707 which cover boys 
were 1131 i.e. $66.26 \%$ and girls were 576 i.e. $33.74 \%$ in $1990-91$. And in 2004-05 the total enrolment was 4171 which covered boys were 2395 i.e. $57.43 \%$, girls were 1776 i.e. $42.57 \%$. Sec./Sr.Sec level in 1990-91 the total enrolment was 805 which covered boys were 567 i.e. $70.43 \%$, girls were 238 i.e. $29.57 \%$. In the year 2004-05 enrolment was 2085 which covered boys were 1290 i.e. $61.87 \%$, girls were 795 i.e. $48.13 \%$ respectively.

\subsection{Dropouts}

The Drop-out Rate represent percentage of pupils who drop out from a given grade or cycle or level of education in a given school year. The method used to calculate Dropout Rates are known as the Apparent Cohort Method.

The rates of drop outs have decreased $42.6 \%$, in $1990-91$ to $29.00 \%$ in $2004-2005$ in primary classes. The rate of dropouts which was $60.9 \%$ in $1990-91$, has come down to $50.84 \%$ in $2004-2005$ in the upper primary classes. Similarly, the dropout rate which was $71.3 \%$ in $1990-91$, has decreased to $61.92 \%$ in $2004-$ 2005 in the secondary classes respectively.

\section{Globalisation And Women Health}

Health and prosperity are meant for everyone but it is too sad that this has always been neglected in the case of Indian women. Women have continued to occupy a secondary and passive role in the patriarchal structure in Indian society. Especially when the society is diverse, multicultural, overpopulated and undergoing rapid but unequal economic growth.

Gender inequalities pervade through the entire spectrum of society. Poverty, geographical locations, social exclusion based on gender, sexuality, disability interact closely with factors like work, housing, environment, education to determine women's health. It is important therefore to understand how women are particularly impacted and their health outcomes. There is a critical need to look at women's health holistically and some of their social environment and lived experience towards understanding their health problems, as against adopting a narrow biomedical approach.

The status of women health is largely reflected by the indicators like female mortality and morbidity, disease burden, reproductive health and encompassing reproductive behaviour, contraction, abortion, maternal mortality and morbidity, gynecological morbidity and infertility ; nutrition, work environment, poverty, sexual harassment and violence against women and its consequences for the health care system of women. Malnutrition of often caused by the gender discrimination in food distribution, presents a serious threat to health of girls and women. Women's risk of premature death and disability is higher during their productive years. Mother mortality rate (47) and Infant mortality rate (70) coupled with educational backwardness of women's result in low social and economic status limiting the women access to education, good nutrition, family planning services and health care.

\section{Globalisation And Modern Day Slavery}

The International Labour Organization estimates that there are 2.45 million trafficking victims who are living in exploitive conditions and another 1.2 million people who are trafficked across and within borders. Women account for at least 56 percent of all trafficking victims (Trafficking in persons report, 2010). Globalization has provided for an easier means of exploiting those living in poverty who are seeking better lives, it also has provided for dramatic improvements in transportation and communications with which to facilitate the physical processing of persons. The State Department report indicates that women are generally lured into slavery through promises of employment as shopkeepers, maids, nannies, or waitresses in developed countries. Upon arriving, these women are then told they have been purchased by someone and must work as a prostitute to repay the enormous debt they suddenly owe. One of the main contributing factors to this increase in trafficking has been the widespread subjugation of women.

Often ethnic minorities or lower class groups are more vulnerable to trafficking, because these women and girls have a very low social status that puts them at risk. Another contributor to the increase in trafficking is political and economic crisis in conflict or post-conflict areas.

South-East Asia and South Asia are considered to be home to the largest number of internationally trafficked persons, with estimates of 225,000 and 150,000 victims respectively. Several NGOs are also involved in awareness campaigns to draw attention to the causes of trafficking in women; specifically, the NCWA tries to change male sexual norms through a national poster campaign with messages showing a child saying "my father does not visit prostitutes.

\section{Conclusion}

Globalization offers women unprecedented opportunities, but equally new and unique challenges. Gender inequality springs from many sources, and it is often difficult to determine which forms of inequality are being eliminated by the effects of globalization, and which are exacerbated. Work toward eliminating gender 
inequality in the framework provided by the Beijing Platform for Action has created awareness, monitoring, and alleviation of the externalities that the new global system creates for women.

Progress toward eliminating gender inequality in the future depends on finding and embracing the occasions, mostly in the political and legal realm, where the global approach strengthens women's security and welfare, and fighting the issues, mostly in the economic realm, where women are made worse off by the new global system.

\section{References}

[1]. Alshar, H. and Barrientos Ed. Women ( 1999) Globalisation and Fragmentation in the developing world, Women's studies at york series, Macmillan Press Ltd.

[2]. Alexander S Preker, Guy Corrin (2004) Health Financing for poor people : Resource mobilization and Risjk sharing,

[3]. Goswami,P.R. Literacy, Information, and Governance in the Digital Era: An Indian Scenario. Libr.Rev. 34;2002;255-70.

[4]. Ghatically, R. (1988) Ed. Women in Indian Society, Sage publication India Pvt. Ltd.

[5]. India Development Report, 2007, 2008

[6]. Human Development Report, UNDP, Oxford University press, 2009

[7]. Rashid, Ali Mohammed. 2000. Impact of Trade Policy Reforms on Industrial Capacity and Employment in Bangladesh. Dhaka: Structural Adjustment Participatory Review Initiative (SAPRI).

[8]. Rajput, Pam,ed. Globalisation and Women. New Delhi; Ashish Publications, 1994.

[9]. Razavi, Shahra, ed. 1999. Special Issue: Gendered Poverty and Well-being. Vol. 30 (3), Development and Change. Oxford: Blackwell Publishers.

[10]. Razavi, Shahra, and Thandika Mkandawire. 2001. Social Policy in a Development Context,paper prepared for the Parliamentary Commission on Swedish Policy for Global Development. Geneva: UNRISD.

[11]. Rodrik, Dani. 1999. The New Global Economy and Developing Countries: Making Openness Work. Washington, D.C.: Overseas Development Council.

[12]. Rodrik, Dani. 2001. The Global Governance of Trade as if Development Really Mattered: Report prepared for the UNDP.

[13]. Siwal,B.R StructuralAdjustment Macro Perspective. Social Welfare.45;1;1998;6-8 \& 48.

[14]. Sood, A.D. How to wire Rural India : Problems and Possibilities of Digital.

[15]. Saith, Ruhi, and Barbara Harriss-White. 1999. The Gender Sensitivity of Well-being Indicators. Development and Change 30 (3):465-497.

[16]. Schild, Veronica. 2001. Engendering the New Social Citizenship in Chile: NGOs and Social Provisioning under Neo-Liberalism. Geneva: UNRISD mimeo.

[17]. Seguino, Stephanie. 1997. Gender Wage, Inequality and Export-Led Growth in South Korea. Journal of evelopment Studies 34 (2): $102-132$.

[18]. Sen, A. 1985. Commodities and Capabilities. Amsterdam: Elsevier Science Publishers.

[19]. Sen, Gita. 1999a. Engendering Poverty Alleviation: Challenges and Opportunities. Development and Change 30 (3):685-692. 